\title{
Mangrove Ecosystem Suitability for Ecotourism Management Recommendation in Iboih Village - Sabang
}

\author{
Cut Nelly $^{1 *}$, Saida Rasnovi ${ }^{1}$, and Zumaidar Zumaidar ${ }^{1}$ \\ ${ }^{1}$ Biology Departement Faculty of Mathematics and Natural Sciences, Universitas Syiah Kuala, Aceh, Indonesia
}

\begin{abstract}
Iboih is one of the villages located in the western area of Weh Island which has been popular as the marine tourism potential. The mangrove ecotourism potential has not been well developed. This study aims to review the mangrove ecosystem suitability as ecotourism area in Iboih Village - Sabang. The methodology used was an explorative survey method. The method of potential suitability determination was scoring and weighting achieved from each parameter reviewed consisting of mangrove density, mangrove species, tidal, biota object, area characteristics, and accessibility. The output of the study found 3 (three) mangrove species including Rhizhophora mucronata, Rhizhophora apiculata, and Avicennia alba. There are supporting biota objects consisting of aquatic dan land fauna. Based on the matrix of potential suitability for mangrove ecotourism, it was found that the tourism suitability index (TSI) as $82.14 \%$ indicating that the mangrove ecosystem in Iboih is very suitable for ecotourism area. The benefit of the study is to provide a contribution to science and become the facilities for environmental education and conservation to the community.
\end{abstract}

Keywords: mangrove ecosystem, ecotourism, Sabang.

\section{Introduction}

Sabang is the town located in Weh Island. Weh Island means a separated island. This island is located in the most western of Indonesia. It is geographically located at

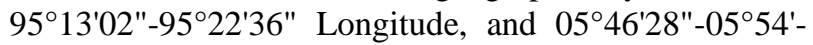
$28^{\prime \prime}$ Latitude and has various natural potential and beauty. Weh Island is famous due to many beaches and blue water. One of the beaches is Iboih Beach. Iboih Beach becomes one of the most favorite tourism objects in Weh Island because of the natural beauty and quite diverse marine biota living along the coastal area [4].

There are several tourism objects in Iboih Village. One of the objects is mangrove tourism. Mangrove tourism has not been well developed and managed even though it can become one alternative tourism beside marine tourism. Iboih Village is located in Sukakarya Sub District, Sabang District located in Weh Island. Weh Island has \pm 15 ha of mangroves ecosystem resources. One of the potentials can be developed is ecotourism development, conservation, recreation activity carried out integrated. This study aimed to review the suitability of the mangrove ecosystem due to the biology aspect of ecotourism management in Iboih Village - Sabang[4].

Today mangroves have become a tourism destination. The tourism industry becomes one of the potential industries because it promotes a sustainable approach and natural resources conservation. The development of tourism destinations promoting natural resources potential is expected to provide a high contribution to improving community incomes, especially in Iboih Village. The development of the mangrove ecosystem refers to environmental tourism and improving the local community prosperous. Iboih Village-Sabang has mangrove ecosystem potential if it is well developed, it can not only as tourism object but also environment and conservation education facilities to the community [5].

The existing mangrove forest located in Iboih Village-Sabang is very potential to be developed as mangrove ecotourism area so the researcher carried out the study of mangrove ecosystem suitability in Iboih Village - Sabang to be established as an alternative tourism destination. The study aimed to review the mangrove ecosystem suitability for the eco-tourism area located in Ibouh Village - Sabang. Today is the proper moment to start developing a mangrove ecotourism location because the vegetation cover resulted from rehabilitation activity is quite tight and very potential to become the ecotourism object in Sabang providing benefits to the various stakeholders [5].

\section{Materials and Methods}

\subsection{Materials}

The materials used in this study were the samples of mangrove types, alcohol, and associated biota. The tools used were GPS, digital camera, stationary and notebook.The study was located on Fisherman hall In Iboh Village Sukakarya Sub District, Sabang City, Aceh Province. It is located on $015^{\circ} 51^{\prime} 25,2^{\prime} \mathrm{N}$ and $095^{\circ} 16^{\prime}$ 01,1' E since May to December 2018 (Figure 1).

* Corresponding author: cutaja95@gmail.com 


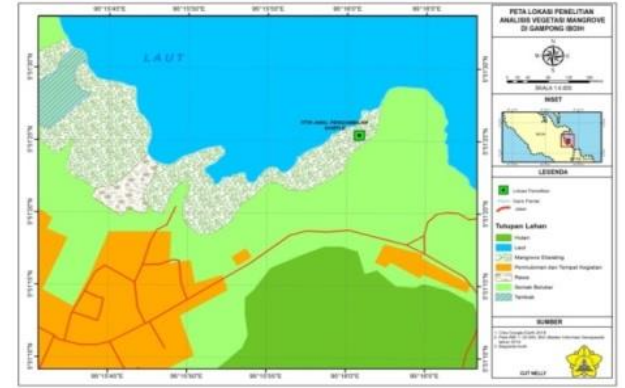

Figure 1. The map of Samples' location

Source: Bappeda Aceh (2014) and Google Earth (2018)

The method used in this study was an exploratory survey method aiming to obtain data and identify mangrove vegetations. There are 2 data collected consisting of flora and fauna data. Fauna data consists of aquatic and terrestrial fauna, while flora data are mangrove vegetations.

The method used for mangrove vegetation data collection is the line transect method (Figure 2). The data collected were in a $20 \mathrm{~m} \times 20 \mathrm{~m}$ plot for the tree stage, in a $10 \mathrm{~m} \times 10 \mathrm{~m}$ plot for pole, in a $5 \mathrm{~m} \times 5 \mathrm{~m}$ plot for a sapling, and a $2 \mathrm{~m} \times 2 \mathrm{~m}$ plot for seedlings. Tree criteria are meet the requirement of the diameter of breast height $(\mathrm{dbh}) \geq 20 \mathrm{~cm}$, the dbh for pole is $10-<20 \mathrm{~cm}$, dbh for a sapling is $<10 \mathrm{~cm}$ which height is $>1.5 \mathrm{~m}$, while criteria for seedling is $\leq 1.5 \mathrm{~m}$ height. The location of the transect line is perpendicular to the coastline towards the seaward with the transect length was $250 \mathrm{~m}$. The total of the transect made was 4 units with a distance between the transect was $50 \mathrm{~m}$. There were 16 plots along the transect.

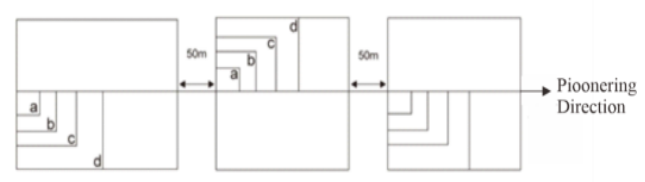

Figure 2. Line Transect method

$$
\text { Description: } \quad \begin{aligned}
& 2 \times 2=\text { seedling } \\
& 5 \times 5=\text { sapling } \\
& 10 \times 10=\text { pole } \\
& 20 \times 20=\text { tree }
\end{aligned}
$$

The method used for aquatic and terrestrial fauna was observed along the transect and interview the community or the fisher surrounding the mangrove ecosystem. While data of bird in mangrove was used binocular in mangrove areas. The observation was done only to watch the existence of the birds in the ecosystem without know the species name [3].

\subsection{Data analysis}

Data analysis was carried out based on the procedure of Bengen (2001) consisting of type density, relative density, frequency, relative frequency, dominance, relative dominance, and important value index.

Data analysis of suitability was carried out to find out the feasibility level of mangrove ecotourism due to the potential of type diversity and area conditions. The
Assessment was conducted based on scoring and value indicated by the score, then it was combined by several variables of value difference among the classes used in determining the classification of area suitability for tourism object [19].

$$
\mathrm{IKW}=\sum(\mathrm{Ni} / \mathrm{Nmax}) \times 100 \%
$$

Description:

IKW =Index of ecosystem suitability for mangrove tourism.

S1 : very feasible: $80-100 \%$

$$
\begin{array}{lll}
\text { S2 } & : \text { Feasible } & : 60-80 \% \\
\text { S3 } & \text { : Conditional } & : 35-60 \% \\
\mathrm{~N} & : \text { Not feasible } & :<35 \%
\end{array}
$$

$\mathrm{Ni} \quad=$ The value of parameter i(quality $\mathrm{x}$ score).

Nmaks =Maximum value of mangrove tourism category

The suitability index percentage can be classified into four categories consisting of veryfisible (IKW 80-100 \%), feasible (IKW 60-80\%), conditional (IKW 35-60\%) and not feasible (IKW $<35 \%$ ). The determination of the

\begin{tabular}{|c|c|c|c|c|c|c|c|c|c|c|}
\hline $\begin{array}{l}N \\
0\end{array}$ & Parameter & $\begin{array}{c}\text { Scor } \\
c\end{array}$ & $\begin{array}{c}\text { S1 } \\
\text { Category }\end{array}$ & $\begin{array}{c}\text { Scor } \\
c\end{array}$ & $\begin{array}{c}\text { S2 } \\
\text { Category }\end{array}$ & Score & $\begin{array}{c}\text { S3 } \\
\text { Category }\end{array}$ & Score & $\begin{array}{c}\mathrm{N} \\
\text { Catcgor } \\
\mathrm{y}\end{array}$ & Score \\
\hline & $\begin{array}{l}\text { Mangrove } \\
\text { Density (100 }\end{array}$ & & & & & & & & & \\
\hline 1 & $\begin{array}{l}\mathrm{m2} \text { ) } \\
\text { Mangrove }\end{array}$ & 4 & 315.25 & 4 & $\$ 10.25$ & 3 & $5 \cdot 10$ & 2 & $<5$ & 1 \\
\hline 2 & Species & 4 & $>5$ & 4 & 3.5 & 3 & 1.2 & 2 & 0 & 1 \\
\hline 3 & Tidal (m) & 3 & $0 .-1$ & 4 & $>1.2$ & 3 & $>2.5$ & 2 & $>5$ & 1 \\
\hline 4 & Biota 0bject & 3 & $\begin{array}{l}\text { Fish, } \\
\text { strimp, } \\
\text { crab, bird, } \\
\text { mollusk, } \\
\text { reptile }\end{array}$ & 4 & $\begin{array}{l}\text { Fish, } \\
\text { shrimp, } \\
\text { crab, } \\
\text { mollusk, }\end{array}$ & 3 & $\begin{array}{c}\text { Fish. } \\
\text { Mollusk }\end{array}$ & 2 & $\begin{array}{l}\text { One of } \\
\text { aquatic } \\
\text { biota }\end{array}$ & 1 \\
\hline 5 & $\begin{array}{l}\text { Arca } \\
\text { Characteristi } \\
\text { es }\end{array}$ & 3 & $\begin{array}{l}4 \\
\text { requirem } \\
\text { ents }\end{array}$ & 4 & $\begin{array}{l}3 \\
\text { requireme } \\
\text { nts }\end{array}$ & 3 & $\begin{array}{l}3 \\
\text { requirem } \\
\text { ents }\end{array}$ & 2 & $\begin{array}{l}1 \\
\text { require } \\
\text { ments }\end{array}$ & 1 \\
\hline 6 & Accessibility & 4 & $\begin{array}{l}4 \\
\text { requirem } \\
\text { ents }\end{array}$ & 4 & $\begin{array}{l}3 \\
\text { requireme } \\
\text { nts }\end{array}$ & 3 & $\begin{array}{l}3 \\
\text { requirem } \\
\text { ents }\end{array}$ & 2 & $\begin{array}{l}1 \\
\text { require } \\
\text { ments }\end{array}$ & 1 \\
\hline
\end{tabular}
suitability value is based not on the multiplication between the score and weight of each parameter. The suitability of coastal tourism in mangrove tourism category should determine six parameters using four assessment classification described in Table 1.

Table 1. The matrix of potential suitability for mangrove ecotourism.

Description : Maximum value $=84$

$\mathrm{S} 1=$ Very feasible which value is $80-100 \%$

$\mathrm{S} 2=$ Feasible which value is $60-<80 \%$

$\mathrm{S} 3=$ Conditional which value is $35-<60 \%$

$\mathrm{N}=$ Not feasible which value is $<35 \%$

Source : Yulianda (2007) in Rozalina (2014), Helmi (2008).

\section{Results and Discussion}

\subsection{The compilation of Mangrove Species}

The existing mangrove forest in Iboih Village - Sabang observed in this study was not natural due to tsunami natural disaster in 2004. Most of the mangrove ecosystems had destroyed, then the various mangrove rehabilitation activities had been carried out by the Non- 
Government Organization (NGO) and Sabang Government from 2005 to 2011 . The analysis output of mangrove vegetation in each phase starting from tree, pole, stapling, and the seedling is explained in Table 2.

Table 2. The composition of mangrove vegetation

\begin{tabular}{|c|c|c|c|c|c|c|c|c|}
\hline No. & Species & AD & $\begin{array}{l}\text { RD } \\
(\%)\end{array}$ & AF & $\begin{array}{c}\mathrm{RF} \\
(\%)\end{array}$ & D & $\begin{array}{l}\text { RD } \\
\text { (\%) }\end{array}$ & IVI \\
\hline & Tree & & & & & & & \\
\hline 1 & Rhizophora mucronata & 0.004 & 45.31 & 1,812 & 45.31 & 0.013 & 43.87 & 137.49 \\
\hline 2 & Rhizophora apiculata & 0.003 & 29.68 & 1,812 & 29.68 & 0.008 & 26.5 & 77,57 \\
\hline \multirow[t]{3}{*}{3} & Avicennia alba & 0.003 & 25 & 1 & 25 & 0.009 & 29.63 & 84.95 \\
\hline & total & 0.010 & 100 & 4 & 100 & 0.029 & 100 & 300 \\
\hline & Pole & & & & & & & \\
\hline 1 & Rhizophora mucronata & 0.02 & 22.38 & 2 & 22.38 & . & . & 44.76 \\
\hline 2 & Rhizophora apiculata & 0.04 & 40,56 & 3.63 & 40,56 & - & - & 81.12 \\
\hline \multirow[t]{3}{*}{3} & Avicennia alba & 0.03 & 37.06 & 3.31 & 37.06 & - & - & 74,13 \\
\hline & total & 0.09 & 100 & 8,938 & 100 & . & - & 200 \\
\hline & Sapling & & & & & & & \\
\hline 1 & Rhizophora mucronata & 0.46 & 42,62 & 11.38 & 42,62 & - & - & 85.25 \\
\hline 2 & Rhizophora apiculata & 0.42 & 39.58 & 10,56 & 39.58 & - & - & 79.16 \\
\hline \multirow[t]{3}{*}{3} & Avicennia alba & 0.19 & 17.8 & 4.75 & 17.8 & - & - & 35.6 \\
\hline & total & 1.07 & 100 & 26.69 & 100 & - & - & 200 \\
\hline & Seedling & & & & & & & \\
\hline 1 & Rhizophora mucronata & 0.53 & 31.48 & 2.13 & 31.48 & - & - & 62.96 \\
\hline 2 & Rhizophora apiculata & 0.58 & 34.26 & 2.31 & 34.26 & - & - & 68.52 \\
\hline \multirow[t]{2}{*}{3} & Avicennia alba & 0.58 & 34.26 & 2.31 & 34.26 & - & - & 68.52 \\
\hline & total & 1.69 & 100 & 6.75 & 100 & - & - & 200 \\
\hline
\end{tabular}

Description : AD: Absolute Density, RD: Relative Density, F: Frequency, FR: Relative Frequency, D:Dominance, DR: Relative Dominance, IVI: Important Value Index

The output explains that the dominant species in every growth phase is a major mangrove (genuine mangrove) consisting of Rhizophora mucronata species. $R$. mucronata dominates in the tree and pole growth phases, while the sapling and seedling growth phases are dominated by Rhizophora apiculata. The different phases of mangrove species found are related to the presence of mangrove forests which is not natural, but they are intentionally replanted after the tsunami disaster. $\quad R$ mucronata species is more dominant because this species is superior in obtaining nutrients, light, and space. Major mangroves are genuine mangroves that only can grow in a mangrove forest environment, have special adaptive forms (breath roots) and have the ability in controlling salt. $R$. mucronata is a growing fast mangrove species because the propagules planted in the ground will have five leaves in three months, and have bigger propagules with more food reserves.

Table 2 explains that the highest density in the tree phase is Rhizophora mucronata as $45,31 \%$ and the lowest is Rhizophora apiculata as $29,68 \%$. The high relative density of $R$. mucronata is because it has a wider area to grow affecting it can well vegetate in the rural areas during having a good saltwater supply.

A species density has a close relationship with its distribution meaning that if a species has a high density, it will occupy a wider space compared to low-density species. A high population will occupy a wider area, meaning that a large relative density species can compete to other species and capable to adjust to the environmental conditions. According to [6], the density can also describe that species having large density can be able to adjust to the plant growth conditions. It means that $R$. mucronata in all growth phases (tree and pole) have a competitive ability to adapt to environmental conditions compared to other mangrove species.

Rhizophora mucronata is a growing fast mangrove species because the propagules planted in the ground will have five leaves in three months, and have a bigger propagules with more food reserves. [17]mentioned that mangrove species have a high adaptation phase, especially in certain species such as propagules of $R$. mucronata species which is generally can grow since sticking to the stem influencing the growth success rate is higher.

Species frequency is one of the vegetation parameters describing the distribution pattern or plant species distribution in the ecosystem or explaining the plants patterns distribution. While the relative frequency is the ratio between a species frequency and the total of all species frequencies, the relative frequency is in percentage [12]. The frequency is influenced by plot output in which mangrove species found.

The mangrove vegetation species distribution in the study area is affected by natural and human factors. It can be seen in the distribution of the tree growth phase found which is distributed artificially. The Mangrove ecosystem rehabilitation program was carried out by NGO and the Sabang City Government in $2005-2011$. According to [9], the species widely distributed has a high frequency meaning that the frequency can describe the species distribution in an ecosystem. $R$. mucronata species for all growth phases (tree and pole) becomes the wide distribution species. According to [14], R.mucronata prefers growing in soft muddy substrates due to the high ability to grow.

Species dominance is the ratio between a species base area (LBD) and the total plot area. The dominance parameter in this study is selected since it is easier and fast to be carried out by measuring the tree diameter on $1.3 \mathrm{~m}$ height from the ground surface. Based on the assumption that the tree cross-section is circular, the species base area (LBD) is calculated using the formula: $\pi \mathrm{d}^{2} / 4$. The dominance calculation is not calculated for sapling and seedling phases because they are still very small for diameter measurements.

Based on the data analysis, the highest relative dominance for tree phase is the Rhizhopora mucronata species as 0.013 meaning that the tree phase of $R$. mucronata species becomes the species dominating in the area. An Important Value Index (INP) is used to determine the role of vegetation species in its ecosystem. The Important Value Index is useful to determine the plant species dominance to other species because there are several species in a community. The vegetation parameters data including density, frequency and dominance values cannot describe as a whole, it requires the calculation of the importance value index to determine the importance values related to community structure. An 
Important Value Index is the sum of the relative density values, relative frequency and relative dominance [7].

For sapling and seedling phases, INP is obtained by totalizing the relative density and relative frequency. If the Importance Value Index of a species is high, the species is very influential to the ecosystem stability. Based on data analysis, the highest INP for tree phase is the Rhizophora mucronata species as $137.49 \%$. It means that R.mucronata species dominate tree and pole phases at the study area.

\subsection{Mangrove Species Diversity}

Species diversity can be used to measure the ability of a community to remain stable to the existing disturbances. The high species diversity values are usually designated as an environmental stability indication. The higher species diversity of a species is affected the more stable of the ecosystem.

Based on the study, it was found 3 mangroves species consisting of Rhizophora mucronata, Rhizophora apiculata, and Avicennia alba. The most common mangrove species found was Rhizophora mucronata with an important value index as 137.49. Mangrove species found were rather low because the ecosystem is not natural but they are replanted. The species found were only limited to 3 species. This low species diversity occurs because the mangrove forests in the fishing center of Iboih Village have been rehabilitated since 2005 2011. [8] mentioned that Rhizophora mucronata is very proper in utilizing solar energy, nutrient or mineral, and water and having competence character to dominate other species. Another reason why Rhizophora mucronata has uniform distribution because the seed can sprout since it still sticks in the stem. The propagule of Rhizophora mucronata generally has grown since it still sticks in the stem affecting the growth successful phase becomes higher.

\subsection{The compilation of Mangrove Species}

Tidal is the periodic process of up and down of seawater affected by the attraction force between the moon and the sun [5]. The tidal graph in the figure is the combination of tidal day 1 carried out on 18 April 2018 and day 2 carried out on 19 April 2018. The relation between the up and down period of the seawater phase in each section can be explained in Figure 3.

The output of tidal measurements showed that the highest tidal on the $1^{\text {st }}$ day was $1.24 \mathrm{~m}$, while the highest tidal on the $2^{\text {nd }}$ day was $1.32 \mathrm{~m}$. The highest tidal range and the output is included in the suitability matrix to the mangrove eco-tourism potential as $>1-2 \mathrm{~m}$. The moon's position when the study carried out was the closest distance to the earth. Tidal type of the study area is diurnal tide meaning that there is one high tidal and one low tidal.

The highest tidal (full tidal) and the lowest tide become the most important factor to determine the mangrove species distribution. There is the highest tidal difference between $1^{\text {st }}$ day and the $2^{\text {nd }}$ day. The $2^{\text {nd }}$ day is lower than the $1^{\text {st }}$ day. It is due to several factors including the wind (wind waves), the attractive force of among the moon - earth - sun, and the earth gravitational and the rotation centrifugal force of the earth, the moon and the sun, and local geographical conditions.

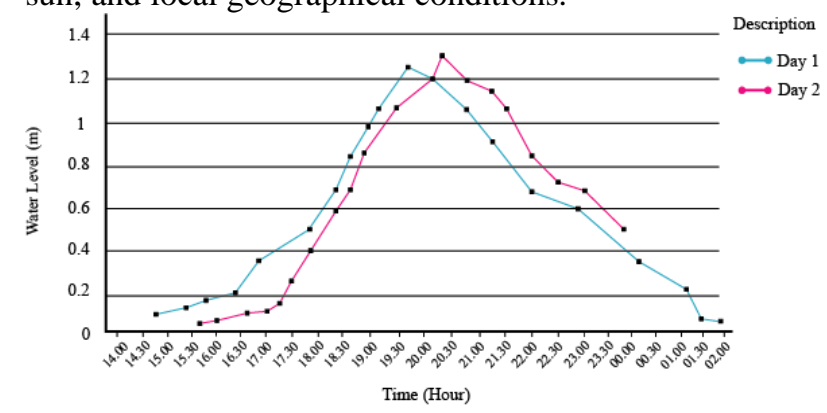

Figure 3. Tidal Graph in Iboih Village.

The tidal in the mangrove area is very effective in determining plant zona and animal habitat in relation to the mangrove ecosystem. Tidal has an important role in the mangrove forest ecosystem, it is not only as mangrove seed distribution but also as the growth media of Rhizophora sp and Avicennia sp seedling. According to [15], the process of seedling distribution is starting from the initial process of floating seedling on the water and distributed to the various places, the seedling rooted and planted in the mud on the lowest tide, and finally growing to straighten. In this phase, The seedlings are dominated by Rhizophora sp. and Avicennia sp.The tidal duration in the mangrove area can impact water salinity change in which the salinity will increase in the high tide and decrease in the low tide. The salinity changes occurring due to the long period of high tide become the boundary factor affecting species distribution horizontally. The water mass movement between freshwater and saltwater impacts organism vertical distribution [17].

\subsection{Biota Object}

Mangrove ecosystem biota objects can observe directly and it can provide both the satisfaction for visitors and more value to a mangrove ecotourism area. Terrestrial fauna can be observed only by documenting the fauna including crustaceans as mud shells found the mangrove forest floor. The bird species found is Egret (Egretta $s p$ ). The reptile species found is a lizard (Emoia atrocostata). Molluscs found is a snail (Littoraria scabra) and mangrove shell (Telescopium $s p$ ). The distribution of mangrove forests is explained in two methods including vertical and horizontal distribution. Vertical distribution is generally carried out by fauna species attached to mangroves, roots, branches, and trunks [19].

Several visual pictures of terrestrial fauna species found in the mangrove ecosystem in Iboih VillageSabang can be shown Figure 4.

The aquatic fauna in the mangrove ecosystem consists of 2 species including the fauna living in the water such as fish species like mudskipper (Periopthalmodon sp.). Mudskipper is a unique fish living in muddy areas. The eyes like a frog. It is called mudskippers due to living and swimming in the mud. Mudskipper adapts by creating the holes in the mud and using it as the habitat. There is also crab (Scylla olivacea) in Crustacea [10]. 
Crab found are dominated by juvenile crabs. Crab in the mangrove forest is located in relatively non-flood soils. Crab adapts by forming holes in soft or moist soil as nests. Other species of fauna found were reptiles such as water snakes (Cerberus sp.) And Laticauda colubrina. The four species of aquatic fauna in mangrove are directly observed in the field. Based on the potential suitability matrix, the mangrove ecotourism has a value of 3 . [1]states that the existence of mangrove fauna becomes the potential to be developed for visitor attractions.

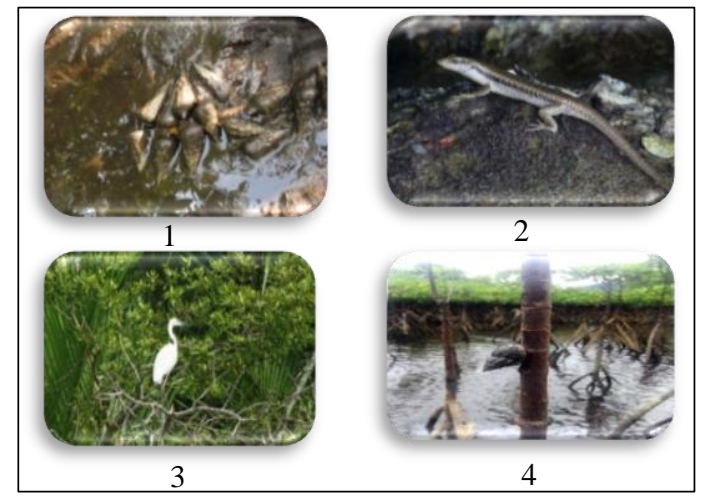

Figure 4. Land fauna found in Iboih village Description : 1. Telescopium sp, 2. Emoia atrocostata, 3. Egretta grazetta, 4. Littoraria scabra

The fauna species found in the mangrove ecosystem in Iboih Village - Sabang can be shown in Figure 5:

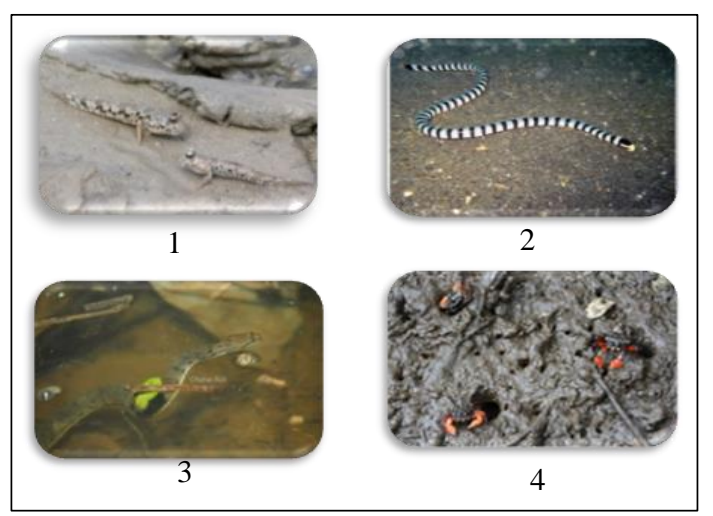

Figure 5. Aquatic fauna found in Iboih village

Description:1.Periopthalmodon gracilis, 2.Laticauda colubrina
3. Cerberrus, $\mathrm{sp}$,
4. Scylla olivaceae

\subsection{Area Characteristic}

The characteristic of an ecotourism area is one of the important assessments. [1] grouped area characteristics into 4 requirements consisting of (1). The existing of an interesting natural object, (2). The beautiful panorama or scenery emphasizing the visual beauty orientation of an area, (3).Landscape such as mountain, hill, bays, river, (4).flora/fauna protected. Based on the assessment, the characteristic area in the study location meets 2 requirements including the beautiful panorama or scenery emphasizing the visual beauty orientation of an area and landscape of bay making the fisherman easier fo find the fish.

\subsection{Accessibility}

Accessibility is one of the supporting factors in developing an area to connect the outside area and related location. The existing facilities and infrastructures can more easily accessible from and to Iboh Village - Sabang. [1] categorized the accessibility into 4 requirements such as (1). The good road toward the location which minimal is pavement road, (2). Several alternative roads toward the location, (3).Many transportations towards the location, (4). Supporting facilities such as the dock. Based on the assessment, the accessibility in the study location meets 2 requirements including minimal is pavement road and Several alternative roads toward the location. More access to the location affect more tourists to come to the location.

\subsection{Mangrove Ecosystem Suitability for ecotourism area}

The study of mangrove ecosystem suitability applies 6 parameters. The Assessment analysis output of the mangrove ecosystem suitability study can be detail explained in Tabel 3.

Table 3. The percentage of mangrove ecotourism suitability.

\begin{tabular}{|c|c|c|c|c|c|}
\hline No & Parameter & Scoring & Output & Score & $\begin{array}{l}\text { Scoring } \mathrm{X} \\
\text { Score }\end{array}$ \\
\hline 1 & $\begin{array}{l}\text { Mangrove } \\
\text { Density } \\
\left(100 \mathrm{~m}^{2}\right)\end{array}$ & 4 & $\begin{array}{l}1000 \\
\text { plants/ha }\end{array}$ & 3 & 12 \\
\hline 2 & $\begin{array}{l}\text { Mangrove } \\
\text { Species }\end{array}$ & 4 & 3 species & 3 & 12 \\
\hline 3 & Tidal & 3 & $1,24-1,32$ & 3 & 9 \\
\hline 4 & Biota Object & 4 & $\begin{array}{c}\text { Fish, crab, } \\
\text { bird, } \\
\text { mollusc,reptil } \\
\mathrm{e}\end{array}$ & 4 & 16 \\
\hline 5 & $\begin{array}{l}\text { Area } \\
\text { Characteristi } \\
\text { cs }\end{array}$ & 4 & $\begin{array}{l}3 \\
\text { requirements }\end{array}$ & 3 & 12 \\
\hline 6 & Accessibility & 4 & $\begin{array}{l}4 \\
\text { requirements }\end{array}$ & 2 & 8 \\
\hline & \multicolumn{4}{|c|}{ Total } & 69 \\
\hline & \multicolumn{4}{|c|}{ IKW $=\sum($ Ni/Nmaks $) \times 100 \%$ Very Feasible } & $82,14 \%$ \\
\hline
\end{tabular}

Based on the output, it results that Tourism Suitability Index (TSI) is $82.14 \%$ and it is feasible. The tourism suitability index is obtained by totalizing the weights $\mathrm{x}$ score divided by the maximum value and then multiplied by $100 \%$, the output is $82.14 \%$. The composition of the mangrove density is quite supportive as 1000 trees/ha in which the good range is above 1000 trees/ha. The species found are 3 species because the mangrove ecosystem in the Iboih Village is replanted after a tsunami disaster, the normal range is $3-5$ species. The tidal is $1.24-1.32$ with the normal range is $\geq 1-2$. The existence of terrestrial and aquatic fauna and area characteristics are 3 , and the last accessibility is included in 2 requirements. All conditions of this area meet the requirements for mangrove ecotourism activities, and overall of the 6 parameters tested are included in the S1 which is very feasible [17].The output of the Tourism Suitability Index (IKW) carried out using the mangrove ecosystems 
suitability matrix is $82.14 \%$ as mentioned in Table 3 . According to [16], the suitability index output is very suitable to be used as mangrove ecotourism. The advantage of my study is to develop Iboih Village in Sabang to become another alternative as a tourism destination, especially in mangrove ecotourism. By the development of mangrove ecotourism, The community is expected to obtain several benefits such as the improvement of household income. They have the skills to create the handicrafts which are made from mangrove leaves and then can be sold as the souvenir. It is required the community awareness to keep and maintain mangrove ecosystems for the sustainability of community life.

\section{Conclusions}

From the output of the mangrove ecosystem area suitability, it can be concluded that mangrove ecosystem in Iboih Village Sabang can be categorized as mangrove ecotourism area development.

\section{Acknowledgments}

The Researcher would like to thank the community and leaders of Iboh Village -Sabang which have actively participated in this study and other saplingholders support this study.

\section{References}

1. Bahar A: Kajian Kesesuaian dan Daya Dukung Ekosistem Mangrove untuk Pengembangan Ekowisata di Gugus Pulau Tanakeke Kabupaten Takalar, Sulawesi Selatan. Tesis. Institut Pertanian Bogor. 2004.

2. Bengen DG: Pedoman Teknis: Pengenalan dan pengelolaan Ekosisten Mangrove. Pusat Kajian dan Sumber Daya Pesisir dan Laut IPB. Bogor. 2001.

3. Bengen, DG: Ekosistem dan sumberdaya pesisir dan laut serta pengelolaan secara terpadu dan berkelanjutan. Prosiding pelatihan pengelolaan wilayah pesisir terpadu. Bogor. 2003.

4. Bappeda: Badan Perencanaan Pembangunan Daerah bekerjasama dengan Badan Pusat Statistik (BPS) Kota Sabang. Sabang dalam Angka Provinsi Aceh. 2014.

5. Dahuri R: Rencana Pengembangan Pengelolaan Pemanfaatan Berganda Hutan Mangrove di Sumatera. PPLH. Institut Pertanian Bogor. 1996.

6. Effendy SP: Proposal Ekowisata Mangrove. Dinas Perikanan dan Kelautan Kota Sabang, Aceh. 2016.

7. Fachrul: Metode Sampling Bioekologi. Bumi Aksara. Jakarta. 2007.

8. Google Earth: Peta Lokasi Vegetasi Mangrove di Gampong Iboih Kota Sabang http://maps.google.com. 2018.

9. Heriyanto NM, Subiandono E: Komposisi dan Struktur Tegakan, Biomassa, potensi Kandungan Karbon di Hutan Bakau Taman Nasional Alas Purwo. Jurnal Penelitian. Hutan dan Konservasi Alam ; 2012; 9(1): 023-032
10. Irwanto: Keanekaragaman Fauna pada habitat Mangrove, Yogyakarta diakses pada tanggal 10 januari 2017. 2006.

11. Januar PB: Keanekaragaman Fauna Vertikal Mangrove dalam Keanekaragaman Fauna Vertikal di Suaka Margasatwa Mapie, Kecamatan Wonomulyo, Kabupaten Polewali Mandar. Tesis, Fakultas Ilmu Kelautan dan Perikanan. Makasar. 2014

12. Jamili, Setiadi D, Qayim I, et al. : Struktur dan Komposisi Mangrove di Pulau Kaledupa, Taman Nasional Wakatobi, Sulawesi Tenggara, Ilmu Kelautan. Jurnal Ilmu Kelautan Indonesia. 2009; 14 (4): 36-45.

13. Kusmana C: Pengelolaan ekosistem mangrove dalam lokakarya nasional berkelanjutan dan berbasis masyarakat tentang pengelolaan ekosistem Mangrove di Jakarta. 2002.

14. Ng, Sivasothi N: Panduan untuk Mangrove Singapura Volume 1 The Ecosystem \& Diversity Plant and Volume 2. The Singapore Science Centre, Singapura. 2001.

15. Nugroho Y: Analisis Karakteristik Fisik - Kimia dan Kesuburan Tanah di Lokasi Hutan Tanaman yang Direncanakan-PT Prima Multibuwana. Jurnal Online Mahasiswa. Program Studi Budidaya, Universitas Lambung Mangkurat, Kalimantan Selatan. 2009; 10 (27).

16. Prihadi DJ, Riyantini I, Ismail MR: Pengelolaan Kondisi Ekosistem Mangrove dan Kapasitas Lingkungan di Kawasan Wisata Bahari Mangrove Karongsong Indramayu. Jurnal Online Mahasiswa, Fakultas Perikanan dan Ilmu Kelautan, Universitas Padjajaran, Bandung. 2018; 13(1): 53-64.

17. Sawitri R, Bismark M, Karlina E: Ekosistem Mangrove sebagai Ekowisata di Kawasan Konservasi untuk Mangrove dan Belalai Monyet di Jurnal online Mahasiswa Kota Tarakan.Penelitian Konservasi dan Rehabilitasi Center, Bogor. 2013; 10(3): 297-314.

18. Setyawan AD, Winarno K, Purnama PC: TINJAUAN: Ekosistem Mangrove di Jawa: 1. Kondisi Saat Ini. Keanekaragaman Hayati. 2003;4(2): 130-142.

19. Tuwo A: Manajemen Ekowisata Pesisir dan Laut: Pendekatan Ekologi, Sosial-Ekonomi, Kelembagaan dan Infrastruktur Wilayah. Brilian Internasional, Surabaya. 2011.

20. Yulianda F: Ekowisata Laut sebagai alternatif untuk penggunaan makalah seminar sumber daya pesisir berbasis konservasi 21 Februari 2007 Departemen Manajemen Sumber Daya Air. FPIK. IPB. 2007.

21. Yusran, Wardah, Nursin A: Karakteristik Karakteristik Kimia Tanah di Berbagai Zona Hutan Bakau di Desa Tumpapa, Kecamatan Bainggi, Kabupaten Parigi Mautong, Jurnal Online Mahasiswa Fakultas Kehutanan, Universitas Tadulako. 2014; 2(1): 17-23. 